\title{
PARTISIPASI PRIA DALAM PROGRAM KELUARGA BERENCANA DI KECAMATAN BANDA SAKTI KOTA LHOKSEUMAWE
}

\author{
Novika Rahnayanti, Muhammad Bin Abubakar ${ }^{1)}$, M. Akmal \\ ${ }^{1}$ Program Magister Administrasi Publik FISIP Universitas Malikussaleh, muhd.a.bakar@gmail.com
}

\section{ABSTRACT}

Participation rate of men in the use of contraception in Banda Sakti district Kota Lhokseumawe is still very low, at only 0,005\%, it's under the national target of 5\%. The purpose of this study was to determine the factors associated with men's participation in Family Planning Program in the working area of Banda Sakti District. This type of research was observational with a cross-sectional approach in 20 Juli 2020 - 8 August 2020, using a questionnaire on 66 respondents. This research was using simple random sampling technic. The result showed that there were $27,3 \%$ of respondents who participated in family planning (25,8\% condoms and 1,5\% vasectomy) and 72,7\% of respondents not participated in family planning. Based on the result of this research, there was significant correlation between quality of service ( $p$ value $=0,003, O R=11,200)$, knowledge ( $p$ value $=0,009, O R=14,385$ ) and social culture $(p=0,000, O R=13,300)$ with male participation in family planning. There was no correlation between sosio demografic (education, income and number children) and access to family planning services with male participation in family planning. It is recommended for managers of Family Planning Program in Banda Sakti district to provide more intensive counseling, increasing socialization of equality, so the participation of men in the Family Planning Program is no longer considered something which is taboo or embarrassing and improving cooperation across sector.

Keywords: Men Participation, Family Planning, MOP/Vasektomi, Condom

\begin{abstract}
ABSTRAK
Partisipasi pria dalam Program Keluarga Berencana khususnya penggunaan kontrasepsi di Kecamatan Banda Sakti Kota Lhokseumawe masih sangat rendah di angka 0,005\%, hal ini masih jauh dari target nasional sebesar 5\%. Penelitian ini bertujuan untuk mengetahui faktor-faktor yang mempengaruhi partisipasi pria dalam mengikuti Keluarga Berencana (akseptor kondom dan MOP) di Kecamatan Banda Sakti Kota Lhokseumawe. Jenis penelitian ini berupa observasional dengan metode pendekatan cross-sectional yang dilaksanakan tanggal 20 Juli 2020 sampai 8 Agustus 2020, menggunakan kuesioner pada 66 responden, dengan teknik simple random sampling. Hasil penelitian ini menunjukkan bahwa terdapat $27,3 \%$ responden yang ikutserta dalam Program Keluarga Berencana dimana 25,8\% menggunakan kontrasepsi kondom dan 1,5\% menggunakan kontrasepsi vasektomi/MOP, sedangkan responden yang tidak menggunakan kontrasepsi sebanyak $72,7 \%$, serta adanya hubungan yang bermakna antara faktor kualitas pelayanan ( $\mathrm{p}$ value $=0,003, \mathrm{OR}=11,200$ ), pengetahuan ( $\mathrm{p}$ value $=0,009, \mathrm{OR}=14,385)$ dan budaya $(\mathrm{p}=0,000, \mathrm{OR}=13,300)$ dengan keikutsertaan pria dalam Program Keluarga Berencana. Tidak ada hubungan bermakna antara sosio demografi (pendidikan, pendapatan, dan jumlah anak) dan akses pelayanan dengan keikutsertaan pria dalam ber-KB di Kecamatan Banda Sakti Kota Lhokseumawe. Disarankan bagi pengelola KB di Kecamatan Banda Sakti Kota Lhokseumawe untuk memberikan penyuluhan yang lebih intensif, meningkatkan sosialisasi tentang kesetaraan, sehingga keikutsertaan laki-laki dalam Program KB tidak lagi dianggap sebagai sesuatu yang tabu atau memalukan sehingga meningkatkan kerjasama lintas sektor.
\end{abstract}

Kata Kunci: Partisipasi Pria, Keluarga Berencana, MOP/vasektomi, Kondom 


\section{PENDAHULUAN}

Sejak penandatanganan kesepakatan Konferensi Internasional tentang Kependudukan dan Pembangunan yang diselenggarakan di Kairo pada tahun 1994, Program Keluarga Berencana di Indonesia mengikuti arus paradigma baru. Hak-hak reproduksi dan kesetaraan gender menjadi agenda utama yang wajib diperhatikan dalam pendekatan ini, tidak lagi bertumpu pada sekedar program pengendalian populasi dan penurunan fertilitas. Konsekuensinya adalah partisipasi pria dalam Program Keluarga Berencana perlu senantiasa ditingkatkan, sementara kaum wanita diberdayakan agar memiliki kapasitas dan kapabilitas dalam mewujudkan keluarga kecil berkualitas (http://www.bkkbn.go.id). Hal ini bermuara pada optimalisasi pemenuhan kesejahteraan dan kebahagiaan (Rizal \& Yulini, 2016).

Konferensi Kairo sudah 26 tahun berlalu. Namun realitasnya masih ditemukan kendala seperti keengganan kaum pria untuk ikutserta dalam Program Keluarga Berencana. Menurut Sutinah (2017), pertimbangan sosial ekonomi mendominasi munculnya resistensi dari para lakilaki yang menolak berpartisipasi. Metode vasektomi dalam Program Keluarga Berencana dianggap mengeluarkan biaya tinggi. Sementara di dalam ruang sosial berkembang asumsi bahwa metode vasektomi dapat menurunkan kejantanan dan menyebabkan impotensi yang kontradiktif dengan harapan masyarakat karena terdapat pandangan bahwa kejantanan diukur dengan jumlah anak yang banyak. Selain itu, pola pikir lain yang terbentuk di benak pemangku kebijakan ialah bahwa mengandung dan melahirkan adalah kodrat wanita sehingga kaum wanita sajalah yang berkewajiban menggunakan alat kontrasepsi. Menjadikan wanita sebagai satu-satunya kelompok sasaran (target group) dapat diukur dari dominasi pengadaan alat kontrasepsi yang diperuntukkan untuk perempuan (Sumadi, 2007).

Partisipasi pria dalam Program Keluarga Berencana masih rendah secara nasional. Demikian pula halnya dalam lingkup Kota Lhokseumawe Provinsi Aceh. Studi Finola (2016) menemukan bahwa keikutsertaan vasektomi/MOP masih tergolong rendah di Kecamatan Banda Sakti. Hal ini didorong oleh masih minimnya pengetahuan tentang metode tersebut. Berdasarkan data tahun 2018 dan 2019, pemakai kontrasepsi vasektomi sebanyak 0 akseptor. Padahal sudah tersedia fasilitas yang cukup memadai sehingga masyarakat seharusnya dapat dengan mudah mengakses pelayanan KB dengan metode vasektomi.

Rendahnya jumlah partisipasi pria ber-KB di Kecamatan Banda Sakti mendorong peneliti untuk melakukan kajian akademis dengan judul Partisipasi Pria dalam Program Keluarga Berencana di Kecamatan Banda Sakti Kota Lhokseumawe. 


\section{METODE PENELITIAN}

Penelitian ini menggunakan pendekatan kuantitatif dengan jenis observasional dan metode cross-sectional. Populasi penelitian sebanyak 131 orang, terdiri dari para akseptor pria dalam Program Keluarga Berencana di Kecamatan Banda Sakti Kota Lhokseumawe. Dari jumlah populasi tersebut ditentukan sampel penelitian sebanyak 66 orang dengan menggunakan metode random sampling (Arikunto, 2002). Data kemudian dikumpulkan dari sampel tersebut melalui penyebaran angket/kuesioner setelah dilakukan uji validitas dan reabilitas terlebih dahulu (Sugiyono, 2012). Pengumpulan data dilaksanakan di Kecamatan Banda Sakti Kota Lhokseumawe. Sementara analisis data yang digunakan adalah analisis univariat dan bivariat (Supranto, 2000; Suharyadi \& Purwanto, 2013).

\section{HASIL DAN PEMBAHASAN}

\section{Kondisi Geografis}

Kota Lhokseumawe memiliki luas wilayah 181,06 $\mathrm{km}^{2}$. Dengan laju pertumbuhan penduduk sebesar 1,93\%, jumlah penduduk pada tahun 2019 mencapai 203.284 jiwa, tersebar di 4 kecamatan yaitu Kecamatan Blang Mangat, Kecamatan Muara Dua, Kecamatan Muara Satu, dan Kecamatan Banda Sakti (BPS, 2019).

Kecamatan Banda Sakti mempunyai luas wilayah 11,24 km², terdiri dari 18 Gampong/Desa dan 2 Kemukiman. Kepadatan penduduk di Kecamatan Banda Sakti yaitu 945 jiwa/km². Terdapat 10 fasilitas kesehatan di Kecamatan Banda Sakti, terdiri dari 2 Puskesmas, yaitu Puskesmas Banda Sakti dan Puskesmas Mon Geudong, Rumah Sakit Tk IV/ Kesrem, Rumah Sakit Umum Sakinah, Rumah Sakit Melati, Rumah Sakit Ibu dan Anak Abby, Rumah Sakit Kasih Ibu, Klinik Vinca Rosea, Klinik Lhokseumawe Husada, dan Klinik Olasvi.

\section{Karakteristik Responden}

Reponden yang paling banyak berumur 31-40 tahun sebesar 48,5\%, sedangkan responden yang paling sedikit dari kelompok umur 51-60 tahun yaitu sebesar 4,5\%. Pendidikan responden yang paling banyak SLTA-Perguruan Tinggi sebesar 77,3\%, diikuti lulus SD-SLTP sebesar 22,7\%. Pekerjaan responden paling banyak yaitu pegawai swasta sebesar 39,4\%, diikuti petani 18,2\%, pedagang $16,7 \%$, lain-lain 13,6\%, dan PNS 12,1\%. Jumlah anak responden paling banyak yaitu

lebih kecil atau sama dengan 3 sebesar 62,1\%, diikuti jumlah anak lebih besar dari 3 orang sebesar $37,9 \%$. 
a. Analisis Univariat

Gambar 1. Karakteristik Responden Berdasarkan Umur

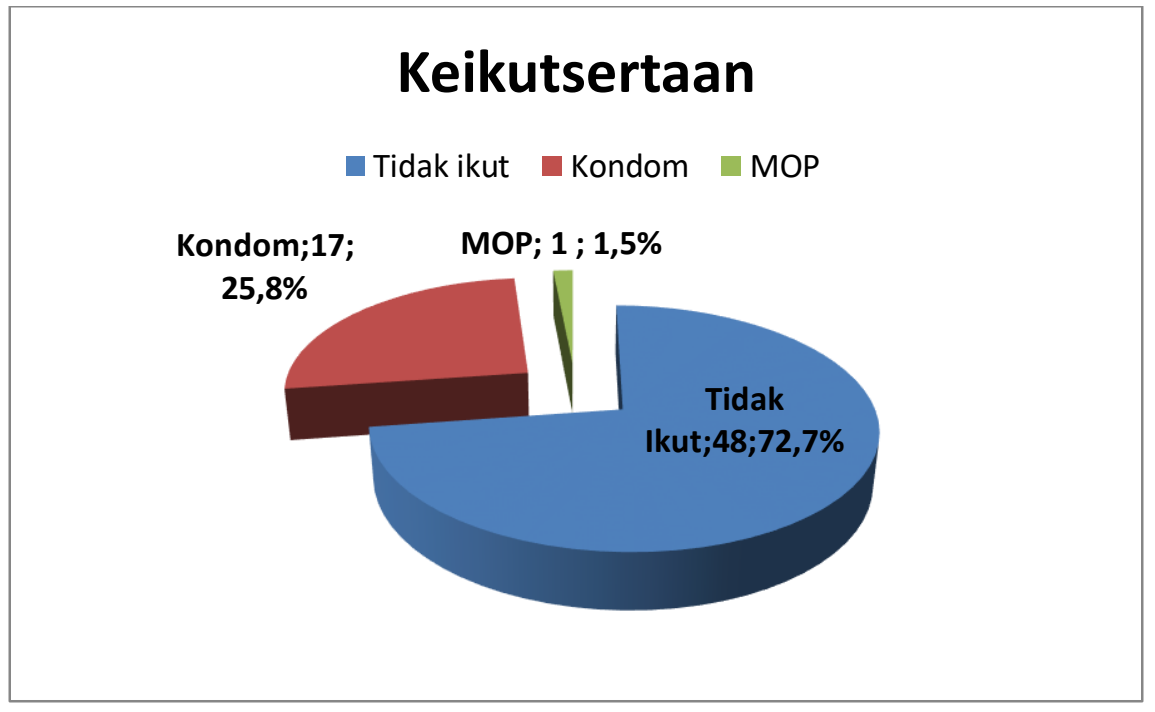

Sumber: data diolah dari hasil penelitian, 2020.

Berdasarkan gambar di atas, menunjukkan hanya sebagian kecil responden menjadi akseptor KB. Dari 66 responden hanya 17 orang $(25,8 \%)$ menggunakan kondom dan hanya 1 orang $(1,5 \%)$ menggunakan MOP. Sementara 48 orang $(72,7 \%)$ tidak menjadi akseptor KB.

\section{b. Analisis Bivariat}

1) Distribusi Responden Berdasarkan Faktor Sosio Demografi

Faktor sosio demografi terdiri dari variabel pendidikan, variabel pendapatan, dan variabel jumlah anak. Gambaran tentang responden berdasarkan variabel faktor sosio demografi terlihat pada Tabel 1. Hasil penelitian menunjukkan bahwa sebanyak 12 orang (18,2\%) yang berpendidikan SD sampai SLTP tidak menggunakan kontrasepsi, sedangkan yang berpendidikan SLTA sampai perguruan Tinggi sebanyak 36 orang $(54,5 \%)$ tidak menggunakan kontrasepsi. Responden dengan pendidikan SD sampai SLTP yang menggunakan kondom 3 orang (4,5\%) dan yang berpendidikan SLTA sampai Perguruan Tinggi yang menggunakan kondom sebanyak 14 orang (21,2\%). Keikutsertaan responden MOP hanya 1 orang (1,5\%) dengan tingkat pendidikan SLTA-Perguruan Tinggi.

Selanjutnya peneliti melakukan uji statistik Chi-Square. Hasil penelitian menunjukkan bahwa di Kecamatan Banda Sakti Kota Lhokseumawe nilai $0,710>$ nilai sig $\alpha(0,05)$ 
merepresentasikan signifikansi probabilitas tingkat pendidikan suami dengan keikutsertaan menjadi akseptor KB.

Tabel 1. Distribusi Responden Menurut Faktor Sosio Demografi di Kecamatan Banda Sakti Kota Lhokseumawe

\begin{tabular}{|c|c|c|c|c|c|}
\hline \multirow{3}{*}{ Keikutsertaan } & \multicolumn{4}{|c|}{ Pendidikan } & \multirow{2}{*}{$\operatorname{Sig}(P)$} \\
\hline & \multicolumn{2}{|c|}{ SD-SLTP } & \multicolumn{2}{|c|}{ SLTA-PT } & \\
\hline & $f$ & $\%$ & $\mathrm{f}$ & $\%$ & \multirow{5}{*}{0,71} \\
\hline Tidak ikut & 12 & 18,2 & 36 & 54,5 & \\
\hline Kondom & 3 & 4,5 & 14 & 21,2 & \\
\hline MOP & 0 & 0 & 1 & 1,5 & \\
\hline \multirow[t]{4}{*}{ Total } & 15 & 22,8 & 51 & $\mathbf{7 7 , 3}$ & \\
\hline & \multicolumn{4}{|c|}{ Pendapatan } & \multirow{7}{*}{0,636} \\
\hline & \multicolumn{4}{|c|}{$<=$ Rp.3.000.000 > Rp.3.000.000 } & \\
\hline & $f$ & $\%$ & $\mathrm{f}$ & $\%$ & \\
\hline Tidak ikut & 22 & 33,3 & 26 & 39,4 & \\
\hline Kondom & 7 & 10,6 & 10 & 15,2 & \\
\hline MOP & 0 & 0 & 1 & 1,5 & \\
\hline \multirow[t]{4}{*}{ Total } & 29 & 44 & 37 & 56,1 & \\
\hline & \multicolumn{4}{|c|}{ Jumlah Anak } & \\
\hline & \multicolumn{2}{|c|}{$>3$ orang } & \multicolumn{2}{|c|}{$<=3$ orang } & \multirow{6}{*}{0,181} \\
\hline & f & $\%$ & $\mathrm{f}$ & $\%$ & \\
\hline Tidak ikut & 20 & 30,3 & 28 & 42,4 & \\
\hline Kondom & 4 & 6,1 & 13 & 19,7 & \\
\hline MOP & 1 & 1,5 & 0 & 0 & \\
\hline Total & 25 & 37,9 & 41 & 62,2 & \\
\hline
\end{tabular}

Sumber: data diolah dari hasil penelitian, 2020.

Selanjutnya hasil penelitian distribusi responden berdasarkan pendapatan diperoleh hasil bahwa pendapatan lebih besar dari Rp.3.000.00,- sebanyak 37 orang $(56,1 \%)$ dan pendapatan lebih kecil dari Rp.3.000.000,- sebanyak 29 orang (43,9\%). Uji statistik Chi-Square menggambarkan bahwa di Kecamatan Banda Sakti Kota Lhokseumawe nilai 0,636 > nilai sig $\alpha(0,05)$ merepresentasikan signifikansi probabilitas tingkat pendapatan dengan keikutsertaan suami menjadi akseptor KB. Pembuktian ini menegaskan tidak ada keterkaitan yang signifikan antara tingkat pendapatan suami dengan keikutsertaan menjadi akseptor KB. 
Hasil penelitian juga menunjukan bahwa responden yang memiliki anak lebih kecil atau sama dengan 3 orang sebanyak 41 orang $(62,1 \%)$ dan yang memiliki anak lebih dari 3 orang sebanyak 25 orang (37,9\%). Uji statistik Chi-Square menggambarkan bahwa di Kecamatan Banda Sakti Kota Lhokseumawe nilai $0,181>$ nilai sig $\alpha(0,05)$ merepresentasikan signifikansi probabilitas jumlah anak dengan keikutsertaan suami menjadi akseptor KB. Pembuktian ini menegaskan tidak ada keterkaitan yang signifikan antara jumlah anak dengan keikutsertaan suami menjadi akseptor KB.

\section{2) Distribusi Responden Berdasarkan Faktor Kualitas Pelayanan}

Berdasarkan Tabel 2 dapat diperoleh gambaran bahwa responden yang menilai kualitas pelayanan baik 30,3\% tidak menggunakan KB, 22,7\% mengunakan kondom, dan 1,5\% menggunakan MOP. Sedangkan responden yang menilai kualitas pelayanan kurang baik 42,4\% tidak menggunakan KB, 3,0\% mengunakan kondom, dan 0\% menggunakan MOP.

Tabel 2. Distribusi Responden Menurut Kualitas Pelayanan di Kecamatan Banda Sakti Kota Lhokseumawe

\begin{tabular}{|c|c|c|c|c|c|c|c|}
\hline \multirow{3}{*}{ Keikutsertaan } & \multicolumn{4}{|c|}{ Kualitas Pelayanan } & \multirow{2}{*}{\multicolumn{2}{|c|}{ Total }} & \multirow{3}{*}{$\operatorname{Sig}(p)$} \\
\hline & \multicolumn{2}{|c|}{ Kurang Baik } & \multicolumn{2}{|c|}{ Baik } & & & \\
\hline & $\mathrm{f}$ & $\%$ & $\mathrm{f}$ & $\%$ & $F$ & $\%$ & \\
\hline Tidak ikut & 28 & 42,4 & 20 & 30,3 & 48 & 73 & \multirow{4}{*}{0,003} \\
\hline Kondom & 2 & 3 & 15 & 22,7 & 17 & 26 & \\
\hline MOP & 0 & 0 & 1 & 1,5 & 1 & 1,5 & \\
\hline Total & 30 & 45,5 & 36 & 54,5 & 66 & 100 & \\
\hline
\end{tabular}

Sumber: data diolah dari hasil penelitian, 2020.

Uji statistik Chi-Square menggambarkan bahwa di Kecamatan Banda Sakti Kota Lhokseumawe nilai 0,003 < nilai sig $\alpha(0,05)$ merepresentasikan signifikansi probabilitas kualitas pelayanan dengan keikutsertaan suami menjadi akseptor KB. Pembuktian ini menegaskan terdapat keterkaitan yang signifikan antara kualitas pelayanan dengan keikutsertaan suami menjadi akseptor KB. 
3) Distribusi Responden Berdasarkan Faktor yang Berhubungan dengan Akses Pelayanan

Tabel 3. Distribusi Responden Menurut Faktor Akses Pelayanan di Kecamatan Banda Sakti Kota Lhokseumawe

\begin{tabular}{|c|c|c|c|c|c|c|c|}
\hline \multirow{3}{*}{ Keikutsertaan } & \multicolumn{4}{|c|}{ Akses Pelayanan } & \multirow{2}{*}{\multicolumn{2}{|c|}{ Total }} & \multirow{3}{*}{$\operatorname{Sig}(p)$} \\
\hline & \multicolumn{2}{|c|}{ Sulit Mengakses } & \multicolumn{2}{|c|}{ Mudah Mengakses } & & & \\
\hline & $\mathrm{f}$ & $\%$ & $\mathrm{f}$ & $\%$ & $\mathrm{~F}$ & $\%$ & \\
\hline Tidak ikut & 19 & 28,8 & 29 & 43,9 & 48 & 73 & \multirow{4}{*}{0,374} \\
\hline Kondom & 4 & 6,1 & 13 & 19,7 & 17 & 26 & \\
\hline MOP & 0 & 0 & 1 & 1,5 & 1 & 1,5 & \\
\hline Total & 23 & 34,8 & 43 & 65,2 & 66 & 100 & \\
\hline
\end{tabular}

Sumber: data diolah dari hasil penelitian, 2020.

Hasil analisis hubungan antara akses pelayanan dengan partisipasi pria sebagai akseptor KB diperoleh sebanyak 29 orang $(43,9 \%)$ pria dengan kemudahan mengakses pelayanan KB tidak menggunakan kontrasepsi dan 19 orang $(28,8 \%)$ pria dengan kesulitan mengakses pelayanan KB tidak menggunakan kontrasepsi. Sedangkan 13 orang (19,7\%) pria dengan kemudahan mengakses pelayanan $\mathrm{KB}$ menggunakan kondom, 4 orang $(6,1 \%)$ pria dengan kesulitan mengakses pelayanan kesehatan menggunakan kondom, dan 1 orang $(1,5 \%)$ pria dengan kemudahan mengakses pelayanan KB menggunakan MOP.

Uji statistik Chi-Square menggambarkan bahwa di Kecamatan Banda Sakti Kota Lhokseumawe nilai $0,374>$ nilai sig $\alpha(0,05)$ merepresentasikan signifikansi probabilitas akses pelayanan dengan keikutsertaan suami menjadi akseptor KB. Pembuktian ini menegaskan bahwa tidak terdapat keterkaitan yang signifikan antara akses pelayanan dengan keikutsertaan suami menjadi akseptor KB.

4) Distribusi Responden Berdasarkan Faktor yang Berhubungan dengan Pengetahuan

Berdasarkan Tabel 4 terlihat bahwa responden yang memiliki pengetahuan tinggi 24,2\% mengunakan kondom dan 1,5\% menggunakan MOP, sedangkan 39,4\% tidak menggunakan KB. Sementara responden yang memiliki pengetahuan rendah 1,5\% mengunakan kondom, sedangkan sebanyak 33,3\% tidak mengunakan kontrasepsi. 
Tabel 4. Distribusi Responden Menurut Faktor Pengetahuan di Kecamatan Banda Sakti Kota Lhokseumawe

\begin{tabular}{|c|c|c|c|c|c|c|c|}
\hline \multirow{3}{*}{ Keikutsertaan } & \multicolumn{4}{|c|}{ Pengetahuan } & \multirow{2}{*}{\multicolumn{2}{|c|}{ Total }} & \multirow{3}{*}{$\operatorname{Sig}(p)$} \\
\hline & \multicolumn{2}{|c|}{ Rendah } & \multicolumn{2}{|c|}{ Tinggi } & & & \\
\hline & $f$ & $\%$ & $\mathrm{f}$ & $\%$ & $\mathrm{~F}$ & $\%$ & \\
\hline Tidak ikut & 22 & 33,3 & 26 & 39,4 & 48 & 73 & \multirow{4}{*}{0,009} \\
\hline Kondom & 1 & 1,5 & 16 & 24,2 & 17 & 26 & \\
\hline MOP & 0 & 0 & 1 & 1,5 & 1 & 1,5 & \\
\hline Total & 23 & 34,8 & 43 & 65,2 & 66 & 100 & \\
\hline
\end{tabular}

Sumber: data diolah dari hasil penelitian, 2020.

Uji statistik Chi-Square menggambarkan bahwa di Kecamatan Banda Sakti Kota Lhokseumawe nilai $0,009<$ nilai sig $\alpha(0,05)$ merepresentasikan signifikansi probabilitas pengetahuan dengan keikutsertaan suami menjadi akseptor KB. Pembuktian ini menegaskan bahwa terdapat keterkaitan yang signifikan antara pengetahuan tentang KB dengan keikutsertaan suami menjadi akseptor KB.

5) Distribusi Responden Berdasarkan Faktor yang Berhubungan dengan Budaya

Tabel 5. Distribusi Responden Menurut Faktor Budaya di Kecamatan Banda Sakti Kota Lhokseumawe

\begin{tabular}{|c|c|c|c|c|c|c|c|}
\hline \multirow{3}{*}{ Keikutsertaan } & \multicolumn{4}{|c|}{ Budaya } & \multirow{2}{*}{\multicolumn{2}{|c|}{ Total }} & \multirow{3}{*}{$\operatorname{Sig}(p)$} \\
\hline & \multicolumn{2}{|c|}{ Tidak Mendukung } & \multicolumn{2}{|c|}{ Mendukung } & & & \\
\hline & $\mathrm{f}$ & $\%$ & $\mathrm{f}$ & $\%$ & $\mathrm{~F}$ & $\%$ & \\
\hline Tidak ikut & 38 & 57,6 & 10 & 15,2 & 48 & 73 & \multirow{4}{*}{0,000} \\
\hline Kondom & 4 & 6,1 & 13 & 19,7 & 17 & 26 & \\
\hline MOP & 0 & 0 & 1 & 1,5 & 1 & 1,5 & \\
\hline Total & 42 & 63,6 & 24 & 36,4 & 66 & 100 & \\
\hline
\end{tabular}

Sumber: data diolah dari hasil penelitian, 2020. 
Berdasarkan Tabel 5 terlihat bahwa proporsi budaya yang tidak mendukung 38 orang $(57,6 \%)$ lebih besar daripada dengan budaya yang mendukung 10 orang $(15,2 \%)$ pada responden penelitian pria yang memilih untuk tidak menggunakan alat kontrasepsi. Sementara proporsi budaya yang tidak mendukung 4 orang $(6,1 \%)$ lebih kecil daripada budaya mendukung 13 orang $(19,7 \%)$ pada responden penelitian pria yang memilih untuk menggunakan kondom, sedangkan 1 orang $(1,5 \%)$ responden dengan kebudayaan mendukung menggunakan MOP.

Uji statistik Chi-Square menggambarkan bahwa di Kecamatan Banda Sakti Kota Lhokseumawe nilai $0,000<$ nilai sig $\alpha(0,05)$ merepresentasikan signifikansi probabilitas budaya dengan keikutsertaan suami menjadi akseptor KB. Pembuktian ini menegaskan bahwa terdapat keterkaitan yang signifikan antara budaya tentang KB dengan keikutsertaan suami menjadi akseptor KB.

\section{Analisis}

a. Hubungan Sosio Demografi dengan Keikutsertaan Pria Mengikuti KB

Hasil analisa bivariat pendidikan dengan nilai $\mathrm{P}$ value $=0,860, \mathrm{OR}=1,667$. Hal ini menggambarkan tidak ada keterkaitan yang berarti antara tingkat pendidikan dengan keikutsertaan suami dalam Program Keluarga Berencana. Temuan ini memperkuat penyataan BKKBN (2000) bahwa tingkat pendidikan tidak berpengaruh jika dikaitkan dengan masalah KB pria karena dalam $\mathrm{KB}$ pria tidak dituntut orang yang berpendidikan tinggi menggunakan kontrasepsi.

Hasil analisis hubungan keikutsertaan pria dengan jumlah pendapatan total keluarga per bulan diperoleh $(\mathrm{P}=0,636, \mathrm{OR}=1,330)$, menggambarkan bahwa tidak terdapat hubungan yang signifikan antara penghasilan total keluarga dengan keputusan menggunakan kontrasepsi pria. Hasil penelitian ini menjadi antitesa studi Sihombing (2018) yang menyimpulkan terdapat hubungan antara penghasilan keluarga dengan keikutsertaan pria menggunakan kontrasepsi.

Sementara itu, terkait dengan jumlah anak diperoleh $\mathrm{p}$ value $=0,181, \mathrm{OR}=1,857$ sehingga dapat disimpulkan bahwa terdapat hubungan yang signifikan antara jumlah anak hidup dengan keputusan pria ikutserta dalam Program Keluarga Berencana. Temuan ini memperkuat studi Darojatun \& Hassan (2015) yang menyatakan bahwa tidak terdapat keterkaitan yang signifikan antara jumlah anak dengan kepesertaan pria dalam Program Keluarga Berencana.

\section{b. Hubungan Kualitas Pelayanan dengan Keikutsertaan Pria Mengikuti KB}

Hasil analisis menggambarkan bahwa terdapat hubungan yang signifikan antara kualitas pelayanan terhadap keputusan menggunakan kontrasepsi pria ( $\mathrm{p}$ value $=0,003$ ), nilai $\mathrm{OR}=11,200$ 
yang berarti bahwa pria yang mendapat kualitas pelayanan baik mempunyai peluang 11,200 kali lebih besar dibandingkan dengan pria yang menyatakan kualitas pelayanan kurang baik. Temuan penelitian ini memperkuat studi Munarsih \& Widaningrum (2014) yang menyimpulkan bahwa kualitas pelayanan memiliki pengaruh pada keikutsertaan suami menggunakan KB.

\section{c. Hubungan Akses Pelayanan dengan Keikutsertaan Pria Mengikuti KB}

Berdasarkan hasil penelitian ( $\mathrm{p}=0,374 \mathrm{RO}=2,293$ ) menunjukkan tidak terdapat hubungan yang signifikan antara akses pelayanan dengan keputusan suami untuk ikutserta menggunakan kontrasepsi. Hasil penelitian ini memperkuat studi Utami (2010), Minarni (2009), dan Nurlina (2011) yang menyatakan tidak terdapat pengaruh jarak tempat pelayanan yang bermakna terhadap keikutsertaan pria sebagai akseptor KB.

\section{d. Hubungan Pengetahuan dengan Keikutsertaan Pria Mengikuti KB}

Tindakan seseorang sangat ditentukan oleh pengetahuan yang dimilikinya (Notoatmodjo, 2007). Utami (2010) dalam penelitiannya menyatakan pengetahuan tentang pengendalian kelahiran dan KB adalah aspek penting yang memiliki pengaruh pada tindakan penggunaan KB. Jadi terdapat hubungan yang signifikan antara pengetahuan tentang alat-alat KB dengan keputusan suami untuk ikutserta dalam Program Keluarga Berencana ( $\mathrm{p}$ value $=0,009$, nilai $\mathrm{OR}=14,385)$. Data ini dapat ditafsirkan bahwa responden yang memiliki pengetahuan yang baik 14,385 kali lebih besar berpeluang untuk berpartisipasi dalam Program Keluarga Berencana dibandingkan dengan responden yang pengetahuannya kurang. Temuan penelitian ini sejalan dengan Faralico \& Sitorus (2018) yang menyatakan pengetahuan memberikan dampak positif terhadap pria untuk mengikuti KB.

\section{e. Hubungan Budaya dengan Keikutsertaan Pria Mengikuti KB}

Selain pengetahuan, budaya juga turut menentukan keputusan pria untuk ikutserta dalam Program Keluarga Berencana ( $\mathrm{p}$ Value $=0.000, \mathrm{OR}=13,300$ ). Hal ini sejalan dengan pandangan Aritonang (2010) yang menyatakan bahwa sebagai mahluk sosial, manusia hidup tidak terlepas dari budaya bahkan dapat dipengaruhi oleh lingkungan budaya dimana ia hidup. Dari data yang diperoleh dapat ditafsirkan bahwa responden dengan budaya mendukung akan 13,300 kali lebih besar ikut serta menggunakan kontrasepsi dibandingkan dengan responden dengan budaya tidak mendukung. Temuan ini memperkuat studi Wijayanti (2004) yang menyimpulkan bahwa kondisi budaya masyarakat yang bersifat patrilinial mempengaruhi keputusan pria berpartisipasi dalam 
Program Keluarga Berencana. Posisi perempuan yang subordinat pada banyak kebudayaan memungkinkan dominasi pria dalam menentukan keputusan untuk ber-KB sehingga kaum perempuan hanya menjadi pihak yang menerima keputusan.

\section{KESIMPULAN DAN SARAN}

Kesimpulan penelitian ini antara lain:

1. Partisipasi pria sebagai akseptor KB (kondom dan vasektomi) di Kecamatan Banda Sakti Kota Lhokseumawe tahun 2019 sebesar 27,3\% dimana 25,8\% menggunakan kontrasepsi kondom dan $1,5 \%$ menggunakan kontrasepsi vasektomi.

2. Ada hubungan kualitas pelayanan dengan keikutsertaan pria ber-KB di Kecamatan Banda Sakti Kota Lhokseumawe $(\mathrm{p}$ value $=0,003, \mathrm{OR}=11,200)$ yang berarti bahwa pria yang mendapat kualitas pelayanan baik mempunyai peluang 11,200 kali lebih besar dibandingkan dengan pria yang menyatakan kualitas pelayanan kurang baik.

3. Ada hubungan pengetahuan dengan keikutsertaan pria ber-KB di Kecamatan Banda Sakti Kota Lhokseumawe ( $\mathrm{p}$ value $=0,009, \mathrm{OR}=14,385$ ), pria yang berpengetahuan tinggi berpeluang 14,385 kali lebih besar mempunyai peluang untuk berpartisipasi menjadi akseptor KB dibanding pria yang memiliki pengetahuan rendah.

4. Ada hubungan budaya dengan keikutsertaan pria ber-KB di Kecamatan Banda Sakti Kota Lhokseumawe ( $\mathrm{p}=0,000, \mathrm{RO}=13,300)$, pria yang budaya mendukung kontrasepsi 13,300 kali lebih besar berpeluang untuk berpartisipasi menjadi akseptor KB dibanding pria yang budaya tidak mendukung.

5. Tidak ada hubungan Sosio demografi (pendidikan, pendapatan dan jumlah anak) dengan keikutsertaan pria ber-KB di Kecamatan Banda Sakti Kota Lhokseumawe.

6. Tidak ada hubungan akses pelayanan dengan keikutsertaan pria ber-KB di Kecamatan Banda Sakti Kota Lhokseumawe.

Saran yang dapat diberikan dari hasil penelitian ini antara lain:

1. Untuk PLKB Kecamatan Banda Sakti: hasil penelitian menunjukkan bahwa partisipasi pria sebagai akseptor KB pria dipengaruhi kualitas pelayanan, pengetahuan tentang KB dan budaya sehingga untuk meningkatkan partisipasi diperlukan metode yang tepat khususnya untuk penyampaian informasi program kondom dan vasektomi serta peningkatan promosi KB pria melalui media baik elektronik maupun cetak dengan variasi kemasan yang menarik sehingga pengetahuan PUS terhadap kontrasepsi meningkat. 
2. Untuk pemerintah Kota Lhokseumawe dan BKKBN Aceh: perlu peningkatan kerjasama lintas sektor untuk memperkuat dukungan dari tokoh agama dan tokoh masyarakat dalam merubah pandangan dan sikap negatif terhadap kontrasepsi pria, dikarenakan masih banyak masyarakat yang berangapan kontrasepsi pria haram.

3. Untuk pengelola program KB Puskesmas dan Kecamatan: meningkatkan sosialisasi tentang kesetaraan dalam penggunaan kontrasepsi tidak harus selalu istri yang ber-KB, suami pun juga harus berpartisipasi sebagai akseptor KB pria.

4. Untuk para peneliti lain: hasil uji bivariat hanya menemukan tiga variabel yang mempunyai hubungan dengan partisipasi pria sebagai akseptor kondom dan vasektomi, maka perlu dilakukan penelitian dengan sampel yang lebih luas, lebih besar dan variabel lebih lengkap.

\section{DAFTAR PUSTAKA}

Arikunto, S. (2002). Prosedur Penelitian Suatu Pendekatan Praktik. Rineka Cipta.

Aritonang, J. (2010) Hubungan Budaya Patriarki terhadap Keputusan WUS Menjadi Akseptor Keluarga Berencana di Lingkungan VI Simpang Selayang Medan Tuntungan Tahun 2010. KTI. Program D-IV Bidan Pendidik Universitas Sumatera Utara.

Badan Pusat Statistik (2019). "Laju Pertumbuhan Penduduk Menurut Provinsi”. www.bps.go.id, diakses 5 Mei 2020.

Badan Kependudukan dan Keluarga Berencana Nasional (2000). Pedoman Penggarapan Peningkatan Partisipasi Pria dalam Program KB dan Kesehatan Reproduksi yang Berwawasan Gender. BKKBN.

Badan Kependudukan dan Keluarga Berencana Nasional (2019). Pencapaian Program KKB Kab/Kota. BKKBN Kota Lhokseumawe.

Darozatun, N. \& Hassan, A. (2015). Faktor yang Berhubungan dengan Keikutsertaan Pria dalam Keluarga Berencana di Kelurahan Cilenggang Serpong Tangerang Selatan. Skripsi. Fakultas Kesehatan Masyarakat Universitas Indonesia.

Faralico, H. \& Sitorus, M. E. (2018). Faktor-faktor yang Berhubungan dengan Keikutsertaan Pria Mengikuti KB di Wilayah Kerja Puskesmas Blang Rakal Kecamatan Pintu Rime Gayo Tahun 2017. Journal of Healthcare Technology and Medicine, 4(1), 51-61.

Finola, C. (2016). Analisis Faktor yang Mempengaruhi Keikutsertaan Suami dalam Memilih alat Kontrasepsi Metode Operasi Pria (MOP) di Kecamatan Banda Sakti Kota Lhokseumawe Tahun 2015. Tesis. Program Magister Ilmu Kesehatan Masyarakat USU Medan.

Minarni (2009). Determinan Kepesertaan Pria dalam KB di Kota Pagar Alam Provinsi Sumatera Selatan Tahun 2009. Tesis. Fakultas Kesehatan Masyarakat Universitas Indonesia. 
Munarsih L. \& Widaningrum A. (2014). Kualitas Pelayanan Keluarga Berencana Pria Vasektomi di Kota Yogyakarta. Skripsi. Program Studi Ilmu Administrasi Negara Universitas Gadjah Mada.

Notoatmodjo, S. (2007). Promosi Kesehatan dan Ilmu Perilaku. Rineka Cipta.

Nurlina, R. (2011). Analisis Partisipasi Pria sebagai Akseptor KB (Kondom dan Vasektomi) di Wilayah Kerja Puskesmas Cipanas Kecamatan Cipanas Kabupaten Lebak Provinsi Banten Tahun 2011. Skripsi. Fakultas Kesehatan Masyarakat Universitas Indonesia.

Rizal, M. \& Yulini, F. (2016). Implementasi Kebijakan Program Keluarga Berencana (KB) di Kabupaten Kampar (Studi Kasus Partisipasi KB Pria di Kecamatan Kampar Kiri Hilir). JOM FISIP, 3(2), 1-11.

Sihombing, R. (2018). Faktor-Faktor yang Berhubungan dengan Penggunaan Kontrasepsi MOP (Metode Operasi Pria) di Kecamatan Siantar Marihat Kota Pematangsiantar Tahun 2018. Tesis. Fakultas Kesehatan Masyarakat Universitas Sumatera Utara.

Sugiyono (2012). Metode Penelitian Kuantitatif, Kualitatif, dan R \&D. Alfabeta.

Suharyadi \& Purwanto (2013). Statistika untuk Ekonomi dan Keuangan Modern Buku 1. Salemba Empat.

Sumadi (2007). Profil Paguyuban KB Pria Prio Utomo Ngudi Raharjo Dukuh Brajan Desa Senden Kecamatan Selo Kabupaten Boyolali. Paguyuban KB Prio Utomo "Ngudi Raharjo". Senden.

Supranto, J. (2000). Statistik Jilid I. Erlangga.

Sutinah (2017). Partisipasi Laki-Laki dalam Program Keluarga Berencana di Era Masyarakat Postmodern. Masyarakat, Kebudayaan, dan Politik, 30(3), 289-299.

Utami, D. (2010). Faktor-Faktor yang Mempengaruhi Keikutsertaan Pria sebagai Akseptor KB (Kondom dan Vasektomi) di Kelurahan Pondok Ranggon Kecamatan Cipayung Jakarta Timur Tahun 2010. Skripsi. Fakultas Kesehatan Masyarakat Universitas Indonesia.

Wijayanti, T. (2004). Studi Kualitatif Alasan Akseptor Laki-Laki tidak Memilih MOP sebagai Kontrasepsi Pilihan di Desa Timpik Kecamatan Susukan Kabupaten Semarang. KTI. Program Studi D IV Kebidanan Stikes Ngudi Waluyo Ungaran. 